\title{
The relationship between dolomite textures and their formation temperature: a case study from the Permian-Triassic of the Sichuan Basin and the Lower Paleozoic of the Tarim Basin
}

\author{
Huang Sijing ${ }^{1,2}$, Huang Keke ${ }^{1,2 *}$, Lü Jie ${ }^{1,3}$ and Lan Yefang ${ }^{1,3}$ \\ ${ }^{1}$ State Key Laboratory of Oil and Gas Reservoir Geology and Exploitation, Chengdu University of Technology, Chengdu, \\ Sichuan 610059, China \\ ${ }^{2}$ Institute of Sedimentary Geology, Chengdu University of Technology, Chengdu, Sichuan 610059, China \\ ${ }^{3}$ College of Earth Sciences, Chengdu University of Technology, Chengdu, Sichuan 610059, China \\ (C) China University of Petroleum (Beijing) and Springer-Verlag Berlin Heidelberg 2014
}

\begin{abstract}
Study of dolomite texture can contribute to understanding the process of dolomitization. This research reports textures and homogenization temperatures of dolomites from the Permian-Triassic strata in the Sichuan Basin and the Lower Paleozoic strata in the Tarim Basin, which provided insights into relationships between dolomite textures and their formation temperatures. Our results are summarized as follows: 1) dolomites with well-preserved texture indicate low dolomitization temperature. However, in certain diagenetic environments, the hydrothermal dolomitization may completely or partially preserve the original texture of dolomites. 2) The formation temperatures of non-planar dolomites are always higher than those of planar dolomites. 3) The formation temperatures of dolomite cements are generally higher than those of replacive dolomites. 4) Although the formation temperatures of saddle dolomite cements have a wide range, they show higher values than those of the planar subhedral to euhedral dolomite cements. Thus, saddle dolomites could generally be an indicator of high precipitation temperature. 5) The fluid $\mathrm{Mg} / \mathrm{Ca}$ ratio is another element controlling dolomite morphology. Micritic dolomites, which precipitate from hypersaline fluids with a high $\mathrm{Mg} / \mathrm{Ca}$ ratio in a subaerial environment could also have features of non-planar anhedral crystal shape because of rapid nucleation and crystallization during dolomitization.
\end{abstract}

Key words: The Permian-Triassic of the Sichuan Basin, the Lower Paleozoic of the Tarim Basin, dolomite textures, formation temperature of dolomites

\section{Introduction}

The origin of dolomites and dolomitized carbonates has long been an interesting topic in carbonate sedimentology. Geochemical and petrographic data have been used to identify the $\mathrm{Mg}$ source, the mechanism of fluid delivery, and the environmental setting favorable for dolomitization, and multiple dolomitization models have been developed to explain the origin of extensive, thick successions of dolostones (Warren, 2000; Hao et al, 2010). Compared with a focus on these macro-scale issues, little consideration has been given to the genetic implication of dolomite textures, and this may be attributed to inadequate textural description. Dolomite rock textures are usually classified simply according to crystal size ranging from fine to coarse

*Corresponding author. email: h-k-k@yeah.net

Received August 24, 2012 crystalline size with no differentiation between textures with different crystal boundary shape and different crystal morphology. According to the mechanism of dolomite crystal growth (e.g. Lewis, 1980; Weeks and Gilmer, 1979; Human et al, 1981), this difference has considerable genetic implications because crystal morphology and its boundary shape are controlled by both nucleation and growth kinetics. Textural criteria under microscopic scale involving the recognition of crystal boundary shape and morphology were proposed by Gregg and Sibley (1984) and Sibley and Gregg (1987), and were used to classify and discuss the dolomite texture (Wang et al, 2010; Huang et al, 2011). However, the formation process and mechanism of these dolomites remains unclear. Therefore, further studies are needed to determine the genetic significance of different dolomite textures at microscopic scale.

The temperature at which crystals grow is one of the 
factors affecting dolomite texture, and it provides valuable clues to interpret the conditions of dolomitization and/or dolomite precipitation. Temperature could affect the mode of crystal growth and ultimately, the texture of these crystals. Some evidence exists in the literature (Brice, 1973; Lewis, 1980; Kirkpatrick, 1981) to support this view. Gregg and Silbey (1984) and Silbey and Gregg (1987) proposed that the crystal boundary shape is controlled by growth kinetics which are partially affected by temperature, and concluded that the boundary between the formation temperature of planar dolomites and that of non-planar dolomites was in the range of $50-60^{\circ} \mathrm{C}$ (Fig. 1). Hence, in some cases, texture may be an important indicator of the diagenetic temperature, and investigating this relationship will be helpful to obtain a deeper understanding of the mechanism of dolomite formation.

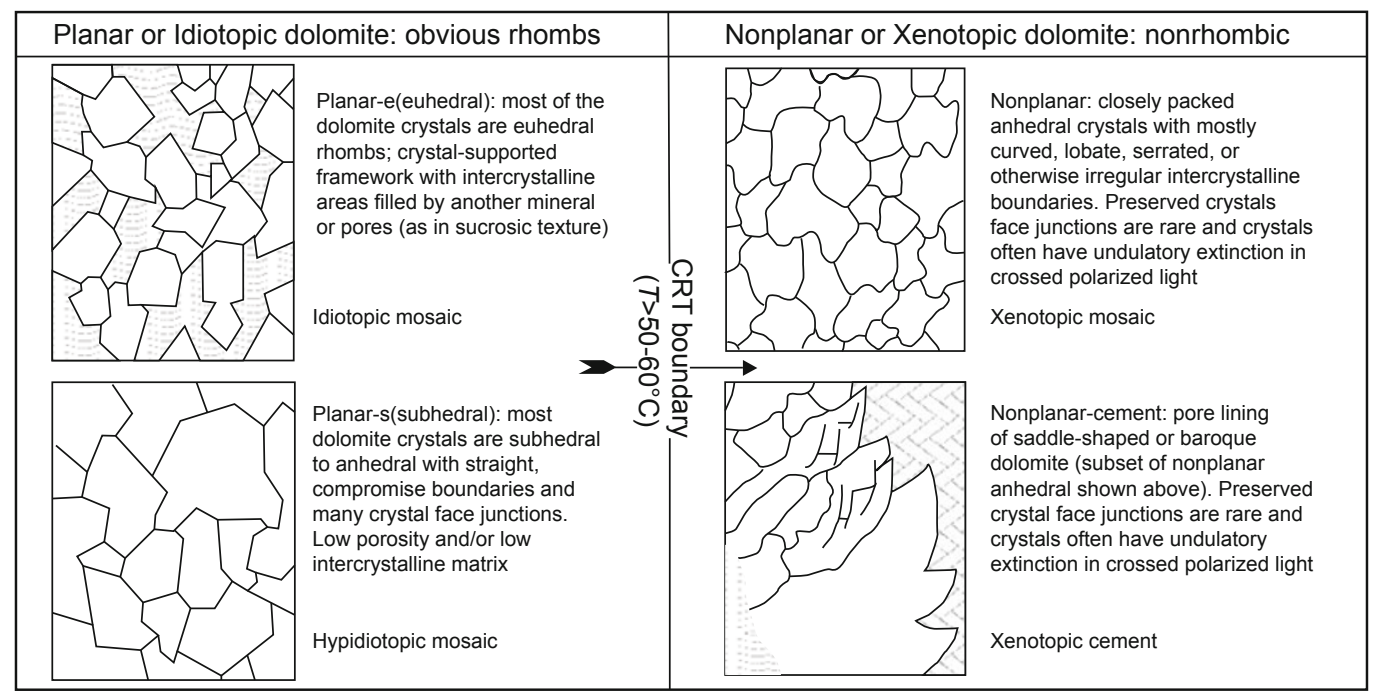

Fig. 1 Common dolomite textures, emphasizing the effect of temperature on the behavior of dolomite crystals. Modified from Gregg and Sibley (1984) and Sibley and Gregg (1987)

Dolomites developed in sequences of the Permian to Triassic strata of the Sichuan Basin and the Lower Paleozoic strata of the Tarim Basin. These sequences include dolomites with well-preserved fabric (e.g. micritic dolomite, grain dolomite, and reef dolomite), poorly-preserved fabric, and fabric-destroyed crystalline dolomite. Based on detailed descriptions of the texture of dolomites, which falls into Gregg and Sibley's (1984) and Sibley and Gregg's (1987) textural category, this study discusses the relationship between dolomite textures and dolomite formation temperatures.

\section{Methods}

The dolomite samples used in this study were collected from Permian to Triassic sequences in the Sichuan Basin and Lower Paleozoic sequences in the Tarim Basin. More than 300 thin sections were examined to classify the textural types, according to the classification system proposed by Gregg and Sibley (1984) and Sibley and Gregg (1987). In this system, the dolomite is initially categorized as having well-preserved fabric, poorly-preserved fabric, and texturedestroyed fabric. Further classification according to the occurrence of the dolomite is made using the two categories: replacive dolomite and void-filling dolomite cements. A more detailed description involves crystal morphology, crystal boundary shape (the degree of curvature of the crystal face), distribution patterns, and crystal size. The crystal morphology includes euhedral, subhedral, and anhedral; the character of the crystal boundary shape ranges from planar to non-planar dolomite crystals; and the contact relation covers two types: 1) dolomitic porphyrites where the crystal is not in contact with neighboring crystals and the intercrystalline area is filled by a limestone matrix and 2) the crystal is in contact with or overlaps the neighboring crystals; the size of the dolomite crystal ranges from fine-grained to extremely coarse-grained crystals.

To prepare the microthermometric thin sections, 22 samples were collected from the Middle Permian Chihsia Formation in the western Sichuan Basin (15 samples), the Lower Triassic Feixianguan Formation in the eastern Sichuan Basin (4 samples), and the Lower Paleozoic Penglaiba Formation in the Tarim Basin (3 samples). The fluid inclusion study was conducted on double-polished $60-\mu \mathrm{m}$-thick rock wafers prepared with a cold technique (the maximum temperature was less than $40{ }^{\circ} \mathrm{C}$ ). The microthermometry measurements were carried out using a calibrated Linkam THMSG 600 heating-freezing stage at the laboratory of the Department of Petroleum Geology in Chengdu University of Technology. The precision of the homogenization temperature (Th) measurements was $\pm 1^{\circ} \mathrm{C}$.

\section{Dolomite textures and controlling factors}

\subsection{Fabric well preserved dolomite}

Dolomite with well-preserved fabric is extensively developed in the Permian-Triassic successions of the Sichuan 
Basin and in the Lower Paleozoic successions of the Tarim Basin. We identified micritic dolomite (Fig. 2(a)), silty dolomite (Fig. 2(b)), grain dolomite (Fig. 2(c) and 2(d)), and reef dolomite with well-preserved fabric. Dolomite crystals that are coarser than silt show a morphology of planar euhedral to subhedral (Fig. 2(b) and 2(c)). However, the finer dolomite crystals (e.g. micritic dolomite) may have anhedral texture (Fig. 2(a), 2(c), and 2(d)). We did not find any measureable two-phase (i.e. gaseous-liquid) fluid inclusions in these dolomite textures. The formation mechanism of these dolomites with well-preserved fabric is related to the sabkha model of hypersaline water conditions (Fig. 2(a) and 2(b)) and the reflux model in a shallow burial environment, indicating a depositional or diagenetic environment at atmospheric temperatures and a formation stage from penecontemporaneous to early burial diagenesis ( $\mathrm{Su}$ et al, 2004; Wei et al, 2005; Huang et al, 2009; Wang et al, 2010). From a dynamic perspective, the high fluid $\mathrm{Mg} / \mathrm{Ca}$ ratio may be a key factor for overcoming the kinetic barrier during the processes of dolomitization (Machel, 2004; Huang, 2010).
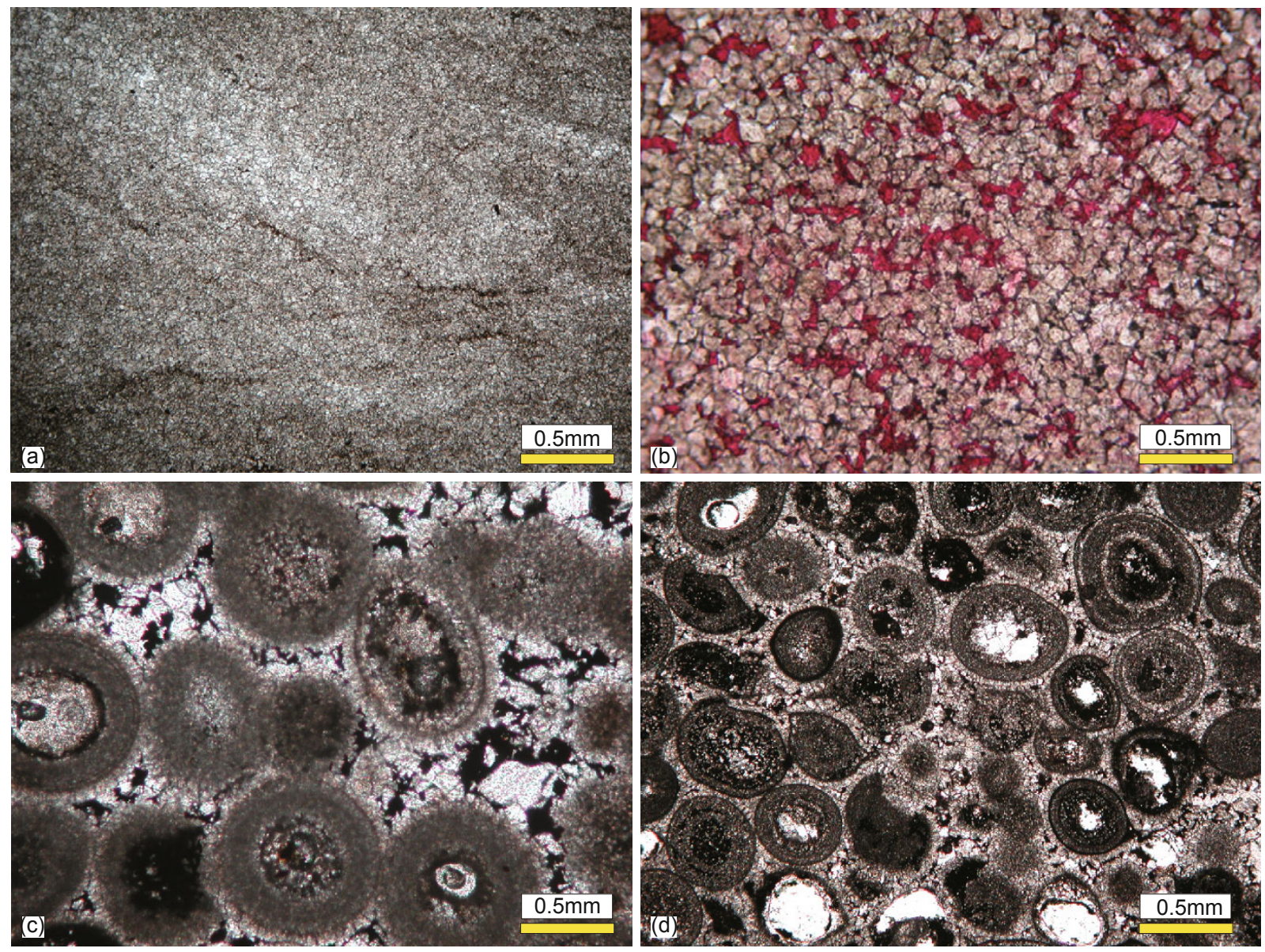

Fig. 2 Microphotographs of dolomites with well-preserved fabric. (a) Micritic dolomites, Well Luo-2, $3196.2 \mathrm{~m}$; (b) Micritic dolomites, Well Heba-1, 4484.76 m, stained with Alizarin Red S. The red parts represent the thermochemical sulfate reduction (TSR) calcites (Huang et al, 2012); (c) Oolitic dolomites, Well Du-5, 4779.8 m; (d) Oolitic dolomites, Well Du-5, $4761.6 \mathrm{~m}$. The photomicrography samples with wellpreserved fabric were taken from the Feixianguan Formation ((a), (c), and (d)) and the Jialingjiang Formation (b), northeast Sichuan Basin. All microphotographs are captured under plane-polarized light.

\subsection{Poorly preserved fabric or fabric-destructive dolomite}

Dolomite with poorly-preserved fabric and crystalline dolomite with destroyed fabrics developed extensively in the Permian-Triassic successions of the Sichuan Basin and the Lower Paleozoic successions of the Tarim Basin. They include the planar subhedral to euhedral crystalline dolomite, dolomite porphyrites, non-planar anhedral crystalline dolomite, planar subhedral to euhedral dolomite cement, and non-planar saddle dolomite cement.

\subsubsection{Planar subhedral to euhedral crystalline dolomite}

Dolomite with poorly-preserved fabric typically developed in the Triassic Feixianguan Formation of the eastern Sichuan Basin, and preserved the original oolitic fabric of the precursor limestone to some extent; it consists of planar subhedral to euhedral crystalline dolomite (Fig. 3(a) and 3(b)). Very few measureable gaseous-liquid fluid inclusions were found and examined in these replacive planar dolomites. It is noteworthy that the measured gaseous-liquid fluid inclusions in these dolomite textures were developed in the pore-lining euhedral and/or overgrowth dolomite cement (Fig. 3(c) and 3(d)).

The lack of gaseous-liquid fluid inclusions in the host dolomite part may indicate that the dolomitization developed in a low temperature environment, and could be related 

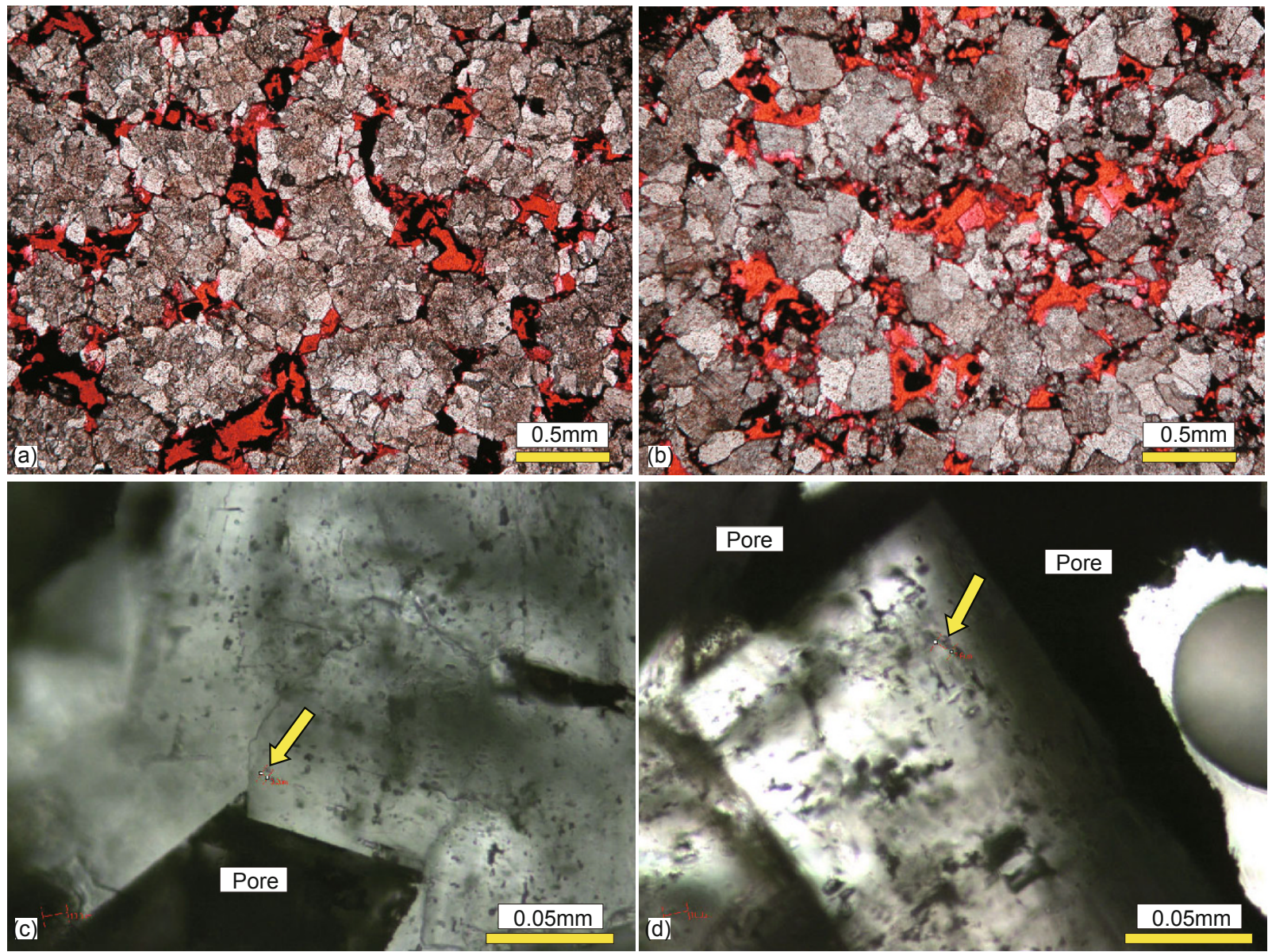

Fig. 3 Microphotographs of dolomites with poorly-preserved fabric and fabric-destroyed crystalline dolomites. Dolomite crystals are planareuhedral to planar-subhedral. The two-phase (i.e. gaseous-liquid) fluid inclusions are poorly developed, and are only found in planar euhedral dolomite cements close to the pore space. (a) Well Luo-2, $3240.3 \mathrm{~m}$ (after Huang et al, 2009) and (b) Well Luo-2, $3258.5 \mathrm{~m}$, northeast Sichuan Basin, red epoxy impregnated, plane-polarized light; (c) and (d) are the corresponding microthermometric wafers of (a) and (b), respectively

to the crystallization process of carbonate minerals at low temperatures (Liu et al, 2004; 2007; Chen and Ge, 2010). If the replacive dolomite was the product of dissolution and precipitation that occurred at elevated temperatures, then measureable fluid inclusions should be easily found in the dolomite. However, the early formed mono-phase (liquid) fluid inclusion could not be easily transformed into gaseous-liquid fluid inclusions during subsequent diagenesis (Goldstein, 2001). In addition, because of the low hardness, high brittleness, and fragile structure of the carbonate minerals, both the mono-phase and two-phase fluid inclusions could have easily cracked and leaked during geological processes to which the rock was subjected (e.g. progressive burial diagenesis and geothermal heating process)(Liu et al, 2008). In this case, these dolomites may be the products of reflux in a hypersaline environment and represent the early burial diagenetic environment of $50-60{ }^{\circ} \mathrm{C}$ (Gregg and Sibley, 1984; Sibley and Gregg, 1987; Su et al, 2004; Wei et al, 2005; Huang et al, 2009; Huang, 2010; Wang et al, 2010). From the dynamic perspective, the high $\mathrm{Mg} / \mathrm{Ca}$ ratio in the dolomitizing fluid might be the key factor in overcoming the kinetic barrier during the process of dolomitization, whereas the temperature plays only a limited role (Machel, 2004; Huang, 2010).

\subsubsection{Dolomite porphyrites}

Planar dolomite porphyrites are the resultant textures of selective matrix dolomitization, and have developed in dolomitic calcites or calcite dolomites in the Permian Chihsia Formation (Fig. 4(a) and 4(b)) and the Triassic Feixianguan Formation (Fig. 4(c) and 4(d)) of the Sichuan Basin, and consist of fine to medium crystals. The dolomitization develops in the lime matrix, and the dolomite rhombs are scattered in the non-dolomitized part. The non-dolomitized part includes bioclasts (e.g. brachiopods and foraminifera; yellow arrow in Fig. 4(a)), lime matrix, and ooids (Fig. 4(c) and 4(d)).

In the Permian Chihsia Formation of the western Sichuan Basin, the partially dolomitized rocks have abundant biologic assemblages (e.g. stenohaline organisms). The stenohaline organisms and the absence of evaporites indicate that the marine water did not provide high $\mathrm{Mg} / \mathrm{Ca}$ ratios for dolomitizing fluids, suggesting that the dolomitization was not associated with fluids of high $\mathrm{Mg} / \mathrm{Ca}$ ratio. Thus, in this case, elevated temperatures may be the key factor for overcoming the kinetic barrier during the processes of dolomitization. Few gaseous-liquid fluid inclusions were found in the planar dolomite porphyrites, indicating homogenization temperatures higher than $60{ }^{\circ} \mathrm{C}$. Therefore, dolomitization at elevated 

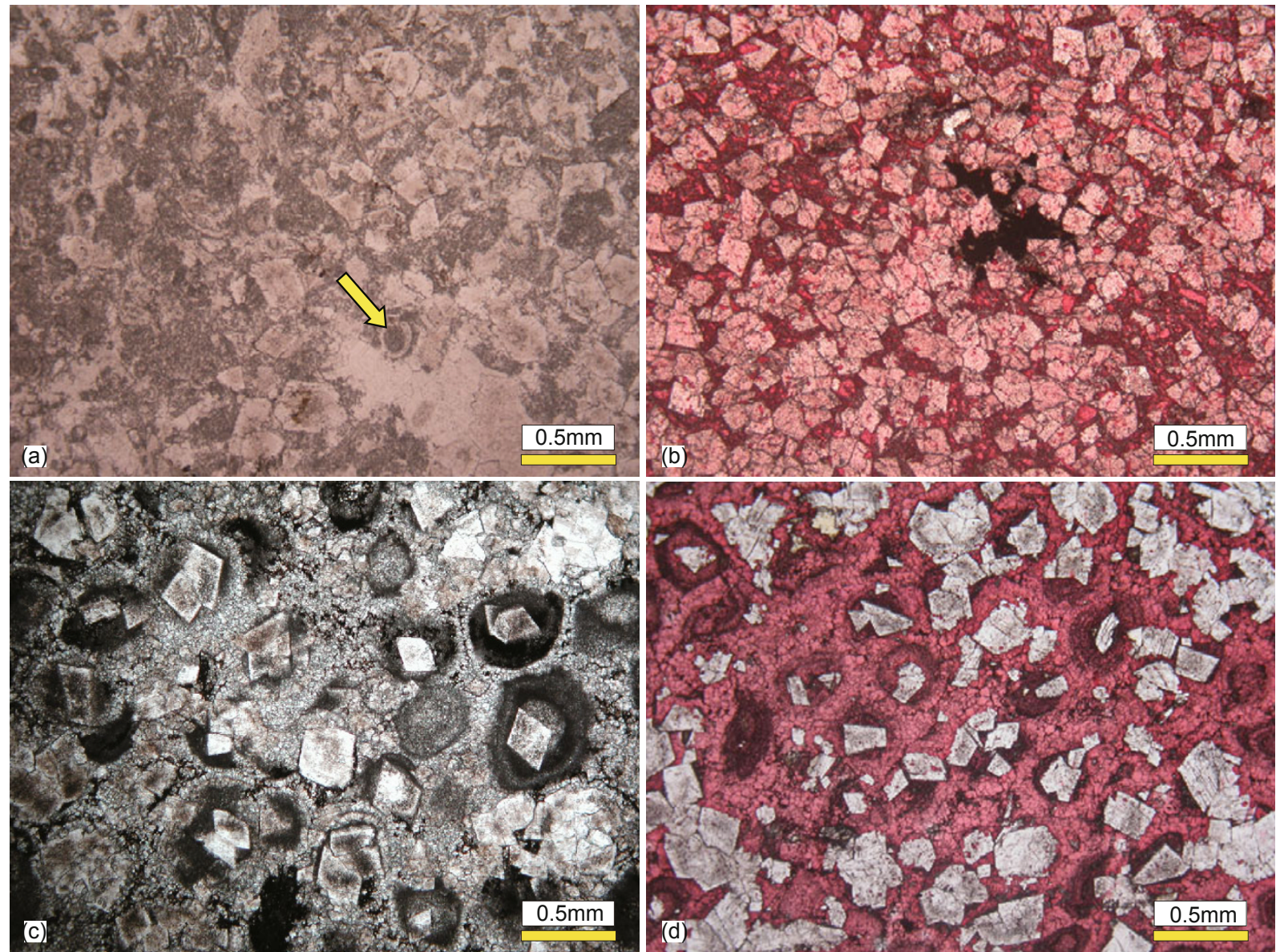

Fig. 4 Thin-section microphotographs of planar dolomite porphyrites. (a) Planar dolomite porphyrites occurring in bioclastic and micritic matrix. Chihsia Formation, Changjianggou section, $80.5 \mathrm{~m}$, western Sichuan Basin; (b) planar dolomite porphyrites occurring densely in micritic matrix. Sample stained with Alizarin Red S, Chihsia Formation, Changjianggou section, 83.7 m, western Sichuan Basin; (c) planar dolomite porphyrites from oolitic limestone. The dolomite rhomb developed in the core part of the ooids. Feixianguan Formation, Well Luo-6, 3929.56 m, eastern Sichuan Basin; (d) planar dolomite porphyrites in oolitic limestone. The dolomite rhomb developed in the core part of the ooids. Sample stained with Alizarin Red S, Feixianguan Formation, Well Luo-6, 3929.56 m, eastern Sichuan Basin. All microphotographs were captured under plane-polarized light.

temperatures (deep burial or hydrothermal) may be the major formation mechanism of these dolomite rhombs, indicating that temperature becomes the key factor for overcoming the kinetic barrier during the process of dolomitization.

In the Triassic Feixianguan Formation of the eastern Sichuan Basin, the partially dolomitized host rock is oolitic limestone, and the depositional fabric of the precursor limestone is well preserved. We found that the dolomite rhombs always occur in the core part of the ooids (Fig. 4(c) and $4(d)$ ), or even replace the ooids completely (Fig. 3(a) and 3(b)). The absence of gaseous-liquid fluid inclusions in these dolomite rhombs may indicate that the dolomitization developed at low temperatures. Therefore, from the dynamic perspective, the high $\mathrm{Mg} / \mathrm{Ca}$ ratio in the dolomitizing fluid may be the key factor for overcoming the kinetic barrier during the process of dolomitization in these samples (Machel, 2004; Huang, 2010).

\subsubsection{Non-planar anhedral crystalline dolomite}

In non-planar anhedral crystalline dolomite the fabric has always been destroyed and the original fabric of the limestone is not preserved, compared with planar subhedral to euhedral crystalline dolomite. This kind of dolomite develops in the Permian Chihsia Formation of the Sichuan Basin and the Cambrian Lower Qiulitage Group and the Ordovician Penglaiba Formation of the Tarim Basin. The samples from the Sichuan Basin can be seen as typical non-planar anhedral dolomite and have larger crystal size (medium to coarse crystal) than planar dolomite (Fig. 5(a) and 5(b)). Abundant gaseous-liquid fluid inclusions that have high homogenization temperatures developed in these dolomites. In addition, the absence of evaporites and abundant stenohaline organisms suggest that the original marine water could not provide dolomitizing fluids with high $\mathrm{Mg} / \mathrm{Ca}$ ratios. Therefore, elevated temperatures may have induced dolomitization. Hence, here, the elevated temperatures may be the key factor in overcoming the kinetic barrier during the process of dolomitization.

\subsubsection{Planar subhedral to euhedral dolomite cement}

Planar subhedral to euhedral dolomite cement occurs in pores, vugs, and fractures of various dolomite rocks (even in limestone) and develops in the Permian and Triassic successions of the Sichuan Basin and the Lower Paleozoic 

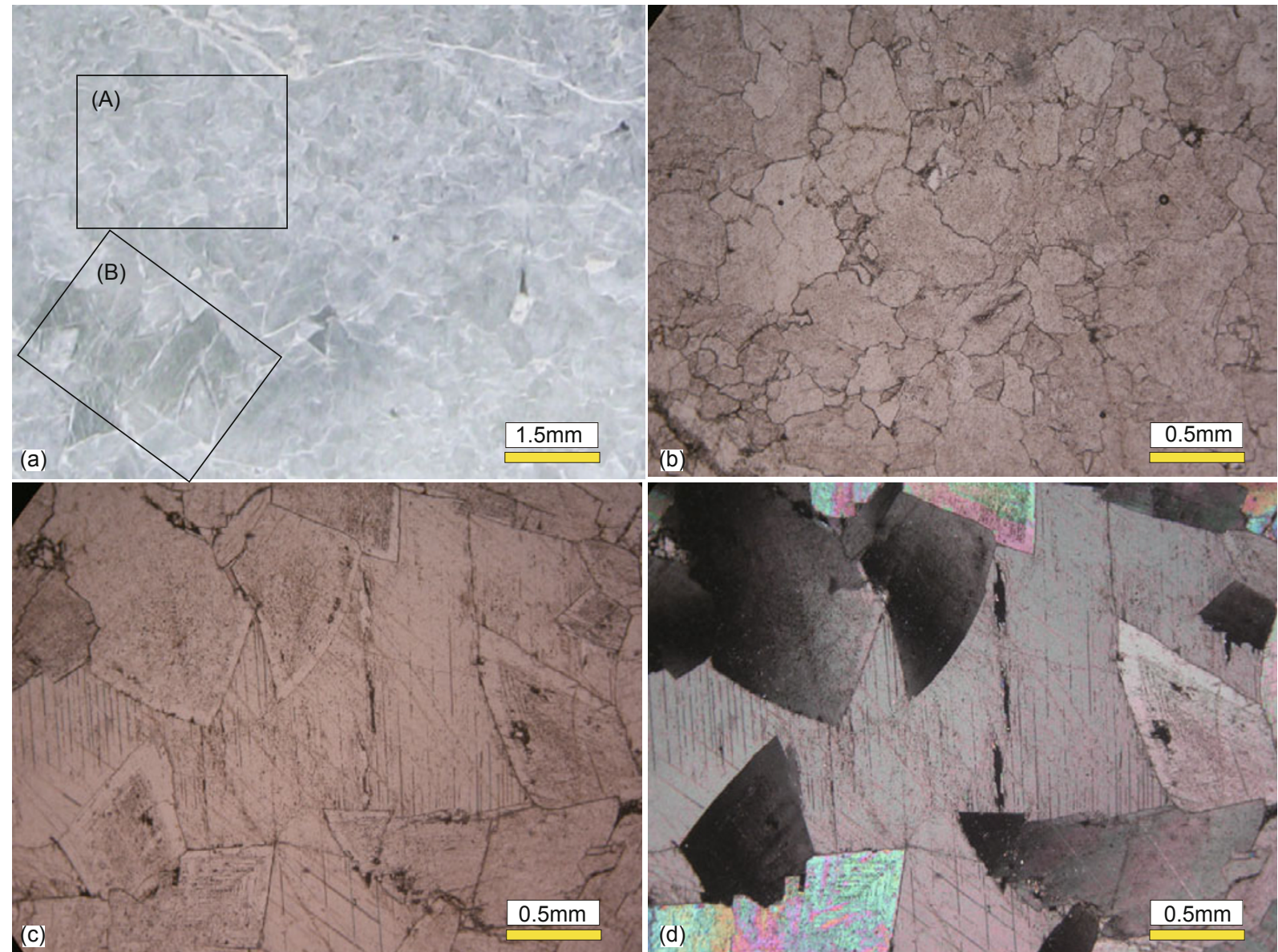

Fig. 5 Thin-section photographs and microphotographs of non-planar anhedral dolomites and non-planar saddle dolomite cements. (a) Photograph of thin section, directly captured by digital camera. (b) Magnified plane-polarized view of box (A) in (a), showing non-planar anhedral dolomite crystals. (c)/(d) A magnified plane-polarized/crossed-polarized view of box (B) in (a), showing non-planar saddle dolomite cements. Note that the saddle dolomites show undulose extinction. Chihsia Formation, Changiianggou section, 48.3 m, western Sichuan Basin.

successions of the Tarim Basin. The crystal sizes vary from fine to coarse or even larger sizes. The major host rock of this kind of cement could be crystalline dolomite with planar subhedral to euhedral texture or with planar subhedral to nonplanar anhedral texture (Figs. 4, 6(a), and 6(b)), and micritic dolomite (Fig. 6(c) and 6(d)). Some of the cements are the overgrowth parts of pre-existing planar subhedral to euhedral dolomite crystals in the host rock, and have abundant two-phase (gaseous-liquid) fluid inclusions. The high homogenization temperatures of the fluid inclusions indicate that dolomitization with elevated temperatures (deep burial or hydrothermal) may be the major formation mechanism for this type of dolomite, and the elevated temperature may be the key factor in overcoming the kinetic barrier during the process of dolomitization.

\subsubsection{Non-planar saddle dolomite cement}

Non-planar saddle dolomite cement occurs in pores or fractures of dolomite with non-planar anhedral texture, has coarse crystal size, and develops in the Permian Chihsia Formation of the Sichuan Basin and the Cambrian Lower Qiulitage Group and the Ordovician Penglaiba Formation of the Tarim Basin. The samples from the Sichuan Basin are typical saddle dolomite cements with coarse or extremely coarse crystal sizes (Fig. 5(c) and 5(d)). These dolomite cements are characterized by strong undulose extinction and curved crystal boundaries. Two-phase (gaseous-liquid) fluid inclusions are abundant in these dolomite cements and have high homogenization temperatures, indicating that dolomitization with elevated temperatures (deep burial or hydrothermal) may be the major mechanism in the dolomitization process, and that the elevated temperatures (higher than $50-60{ }^{\circ} \mathrm{C}$ ) were the key factor in overcoming the kinetic barrier during the dolomitization.

\section{Inclusion homogenization temperatures of dolomite with different textures}

\subsection{Overview}

We performed microthermometry testing on samples collected from the Permian and Triassic successions of the Sichuan Basin and the Lower Paleozoic successions of the Tarim Basin. The fluid inclusions in various dolomite textures were analyzed to determine the homogenization temperatures. Fig. 7 shows the average homogenization temperatures of different dolomite textures. 

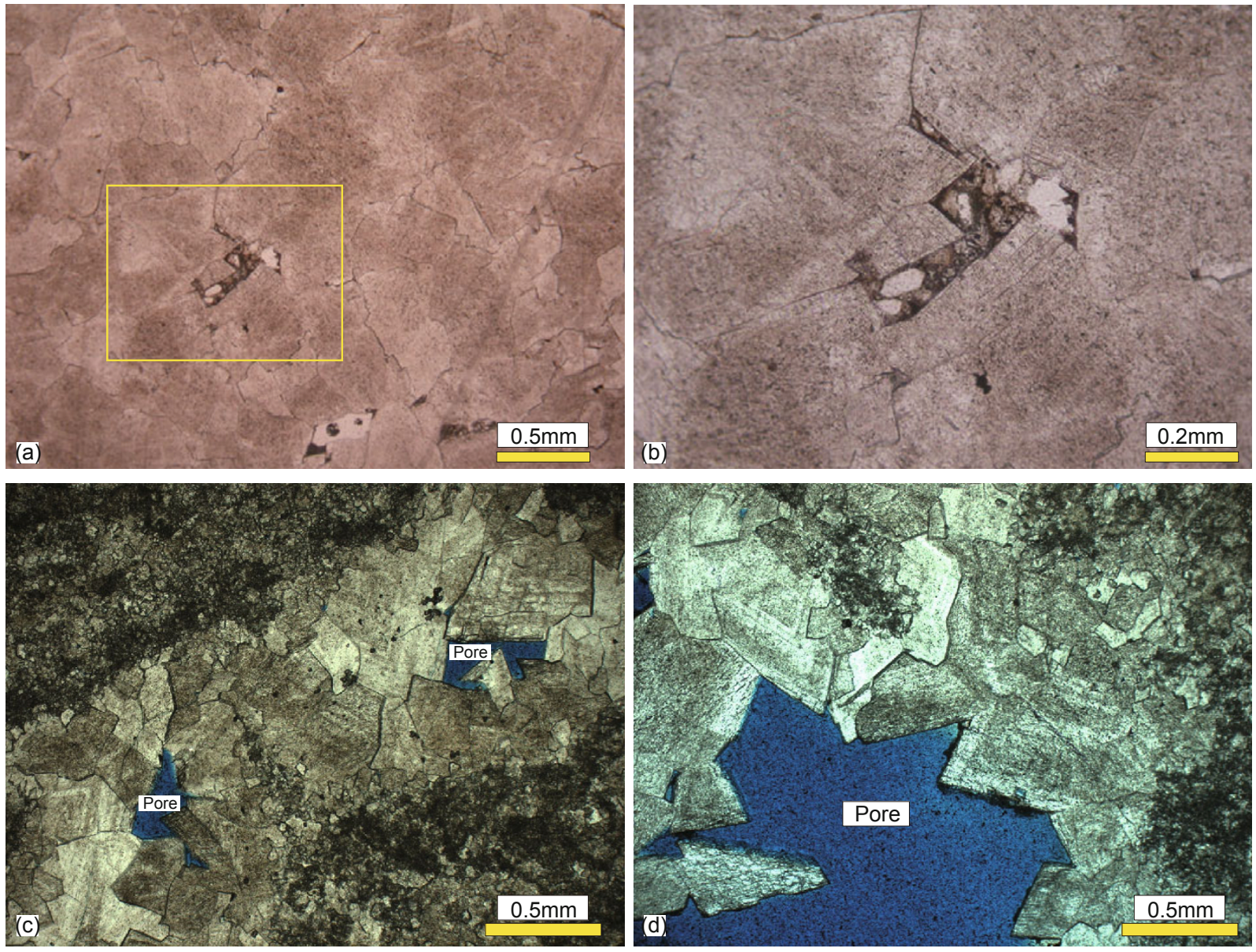

Fig. 6 Thin section microphotographs of planar subhedral dolomites and planar euhedral dolomite cements. (a) The transition from planar subhedral dolomite crystals to planar euhedral dolomite cements. (b) Magnified view of yellow-lined area in (a), plane-polarized, Chihsia Formation, Well WJ1, $4041.22 \mathrm{~m}$, western Sichuan Basin. (c) Section showing planar euhedral dolomite cement filling the voids/fractures in micritic dolomite. The distribution mode of the dolomite crystal size is bimodal. Generally, micritic dolomites are dominant. (d) Planar subhedral to euhedral dolomites in pores or fractures. The planar euhedral dolomite cements, which occurred at the central part of the pore space, are the most recent products (after Huang, 2010). Microphotographs of (c) and (d) are blue epoxy impregnated and under plane-polarized light. Cambrian Lower Qiulitag Group, Well Tashen-1, 7857.7 m, Tarim Basin.

Among various dolomite phases, the dolomite cement has more gaseous-liquid fluid inclusions than the replacive dolomite phases. In the two dolomite cement textures, the non-planar saddle dolomite cement has more gaseous-liquid fluid inclusions than the planar subhedral to euhedral dolomite cement (Table 1). Among the various replacive dolomite textures, the non-planar anhedral dolomite has more gaseousliquid fluid inclusions than the micritic or silty dolomite and the replacive planar subhedral to euhedral dolomite. Measureable two-phase fluid inclusions were rare (Table 1) in the latter two textures. In the samples from the Triassic Feixianguan Formation of the northeastern Sichuan Basin, the crystalline dolomite with residual (poorly-preserved) oolitic fabric consists mainly of fine-crystalline, planar subhedral to euhedral dolomite crystals (Fig. 3). The homogenization temperature data in these samples were all measured in the pore-filling cement part (or outer part) of the planar subhedral to euhedral dolomite crystals. No measureable gaseous-liquid fluid inclusions were found in the core part or inner part (i.e. non-cement part) of the planar subhedral to euhedral dolomite crystals.

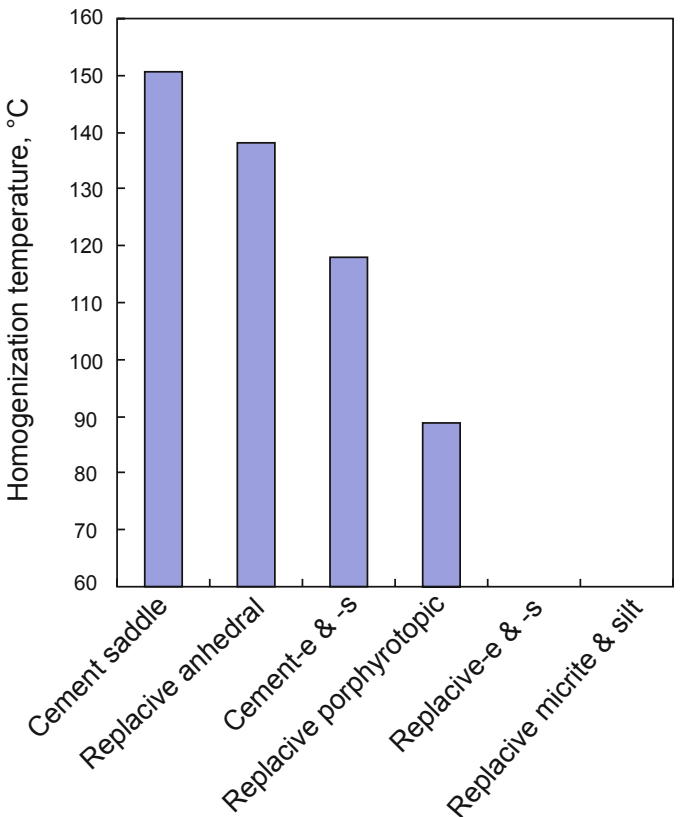

Fig. 7 Histogram of mean homogenization temperatures of fluid inclusions in different dolomite phases in the Permian to Triassic successions of the Sichuan Basin and the Lower Paleozoic of the Tarim Basin 
Table 1 Homogenization temperatures of fluid inclusions in different dolomite phases. Samples were taken from the Permian-Triassic successions of the Sichuan Basin and the Lower Paleozoic formations of the Tarim Basin

\begin{tabular}{|c|c|c|c|c|c|c|c|c|c|}
\hline \multicolumn{2}{|r|}{ Texture } & \multicolumn{2}{|c|}{ Area and Unit } & \multirow{2}{*}{ Occurrence } & \multicolumn{3}{|c|}{$\begin{array}{l}\text { Homogenization } \\
\text { temperatures, }{ }^{\circ} \mathrm{C}\end{array}$} & \multicolumn{2}{|c|}{$\begin{array}{l}\text { Features of } \\
\text { fluid inclusions }\end{array}$} \\
\hline $\begin{array}{l}\text { Crystal } \\
\text { boundary } \\
\text { shape }\end{array}$ & $\begin{array}{c}\text { Crystal } \\
\text { morphology }\end{array}$ & Area & Unit & & Mean & Maximum & Minimum & Number & $\begin{array}{c}\text { Degree of } \\
\text { development }\end{array}$ \\
\hline Nonplanar & Saddle & $\begin{array}{c}\text { Western } \\
\text { Sichuan Basin }\end{array}$ & $\begin{array}{l}\text { Middle } \\
\text { Permian }\end{array}$ & Cements & 151 & 243 & 91 & 55 & Very high \\
\hline \multirow{3}{*}{ Nonplanar } & \multirow{3}{*}{ Anhedral } & $\begin{array}{c}\text { Western } \\
\text { Sichuan Basin }\end{array}$ & $\begin{array}{l}\text { Middle } \\
\text { Permian }\end{array}$ & Replacive & 140 & 203 & 81 & 25 & High \\
\hline & & Tarim Basin & Lower Paleozoic & Replacive & 133 & 159 & 111 & 10 & High \\
\hline & & Total & & & 138 & 203 & 81 & 35 & High \\
\hline Planar & Porphyrites & $\begin{array}{c}\text { Western } \\
\text { Sichuan Basin }\end{array}$ & $\begin{array}{l}\text { Middle } \\
\text { Permian }\end{array}$ & Replacive & 89 & 102 & 82 & 5 & Low \\
\hline \multirow{4}{*}{ Planar } & \multirow{4}{*}{ Subhedral-euhedral } & $\begin{array}{c}\text { Northeast } \\
\text { Sichuan Basin }\end{array}$ & Lower Triassic & Cements & 116 & 127 & 99 & 10 & High \\
\hline & & $\begin{array}{c}\text { Western } \\
\text { Sichuan Basin }\end{array}$ & $\begin{array}{l}\text { Middle } \\
\text { Permian }\end{array}$ & Cements & 108 & 198 & 67 & 26 & High \\
\hline & & Tarim Basin & Lower Paleozoic & Cements & 138 & 176 & 113 & 14 & High \\
\hline & & Total & & & 118 & 198 & 67 & 50 & High \\
\hline Planar & Subhedral-euhedral & All area & All units & Replacive & & & & & Very low \\
\hline Total & & & & & 134 & 243 & 67 & 145 & \\
\hline
\end{tabular}

The fluid inclusions found in our samples are colorless and usually have regular shapes such as rhombohedral or rectangular, while round and irregular shapes are less common. According to the physical form classification, the inclusions could be divided into two main categories: monophase (aqueous phase) inclusions and two-phase (aqueous and gaseous phase) inclusions. The gas bubble in the twophase inclusions occupies $10 \%-20 \%$ of the total inclusion volume. Goldstein (2001) proposed a series of criteria for distinguishing the primary and secondary fluid inclusions. According to the criteria, all the fluid inclusions in our samples are primary aqueous-gaseous fluid inclusions.

\subsection{Homogenization temperature}

1) In the dolomites with well-preserved fabric, the dolomite textures of replacive origin, including dolomicrite (in the micritic dolomite, grain dolomite, and reef dolomite) and fine-crystal dolomite (in silty dolomite) do not have measureable gaseous-liquid fluid inclusions and many monophase (i.e. liquid) fluid inclusions, suggesting that these dolomite textures have low replacive temperatures. In the crystalline dolomites, the replacive planar euhedral dolomite crystals, especially the dolomite samples with residual oolitic fabrics from the Triassic Feixianguan Formation of the Sichuan Basin (Fig. 3), also have very few measureable gaseous-liquid fluid inclusions and abundant mono-phase (i.e. liquid) fluid inclusions. Although the formation temperatures could not be determined by microthermometric analysis, the characters of the poorly developed two-phase and well developed mono-phase fluid inclusions may indicate low formation temperatures (Liu, 1995; Braithwaite and Rizzi, 1997; Goldstein, 2001; Tao, 2004).

2) Non-planar saddle dolomite cements were found mainly in samples from the Permian Chihsia Formation of the western Sichuan Basin, and have maximum and average homogenization temperatures of $243{ }^{\circ} \mathrm{C}$ and 151 ${ }^{\circ} \mathrm{C}$, respectively. Most of the temperature values lie between $110{ }^{\circ} \mathrm{C}$ and $180{ }^{\circ} \mathrm{C}$ (Table 1 ; Fig. $8(\mathrm{a})$ ). The average $T_{\mathrm{h}}$ of the two-phase fluid inclusions within the planar euhedral dolomite cements is $118^{\circ} \mathrm{C}$, and is lower than the average $T_{\mathrm{h}}$ value of the saddle dolomite cements. In microthermometric analysis, the planar dolomite cements may sometimes be indistinguishable from the non-planar dolomite cements, possibly causing the partial overlap of the homogenization temperatures between these two textures. However, the crystallization temperatures of the planar dolomite cements are generally much lower than those of the non-planar dolomite cements (Fig. 8).

3) The non-planar anhedral dolomites of replacive origin 
also have higher homogenization temperatures $\left(80-200{ }^{\circ} \mathrm{C}\right.$, average $138{ }^{\circ} \mathrm{C}$; Fig. 8(b)) than those of the planar euhedral dolomite cements (Fig. 8(c)). However, the homogenization temperatures of the non-planar anhedral dolomites are obviously lower than those of the non-planar saddle dolomite cements (Figs. 8(a) and 8(b)).

4) Among the various measured dolomite textures, the planar dolomite porphyrites have the lowest homogenization temperatures $\left(80-100^{\circ} \mathrm{C}\right.$; average $89^{\circ} \mathrm{C}$; Fig. $\left.8(\mathrm{~d})\right)$, and are the least common (Table 1).

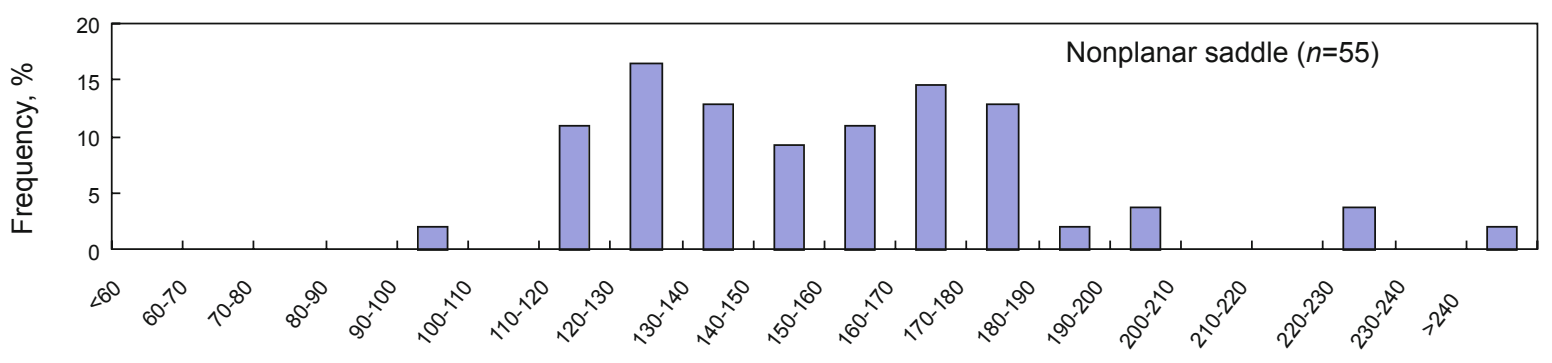

(a)

Homogenization temperature, ${ }^{\circ} \mathrm{C}$

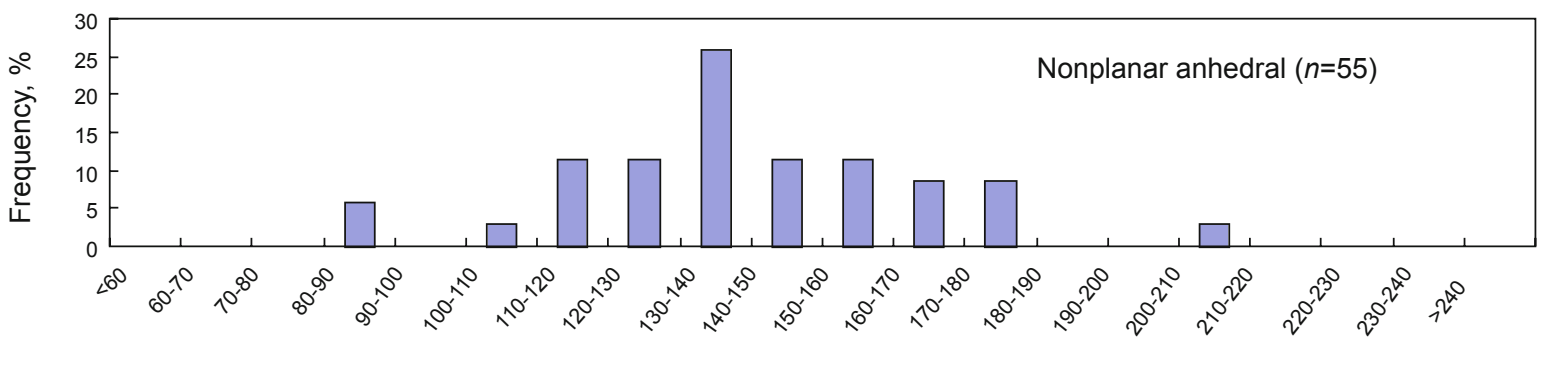

(b)

Homogenization temperature, ${ }^{\circ} \mathrm{C}$

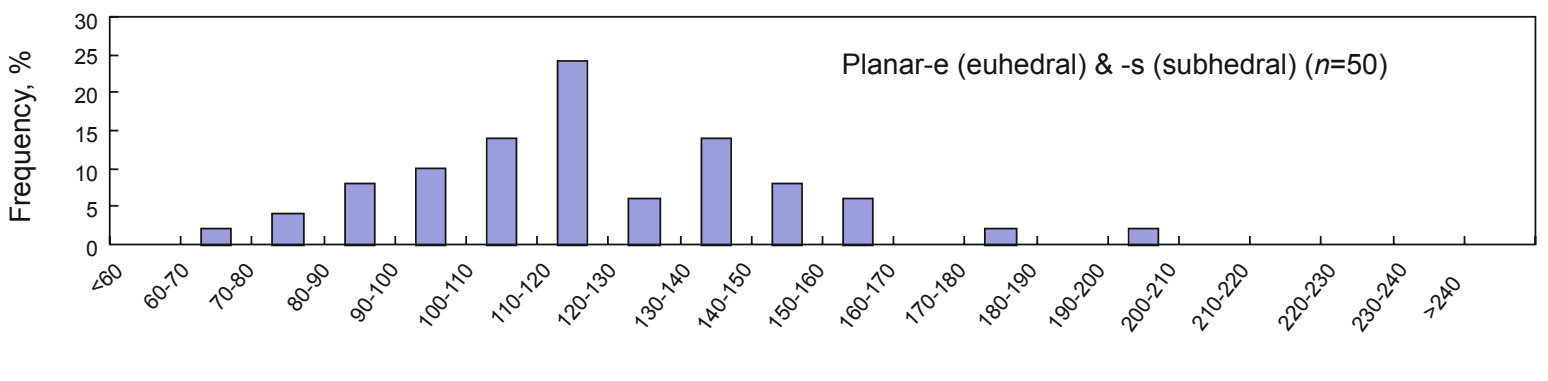

(c)

Homogenization temperature, ${ }^{\circ} \mathrm{C}$

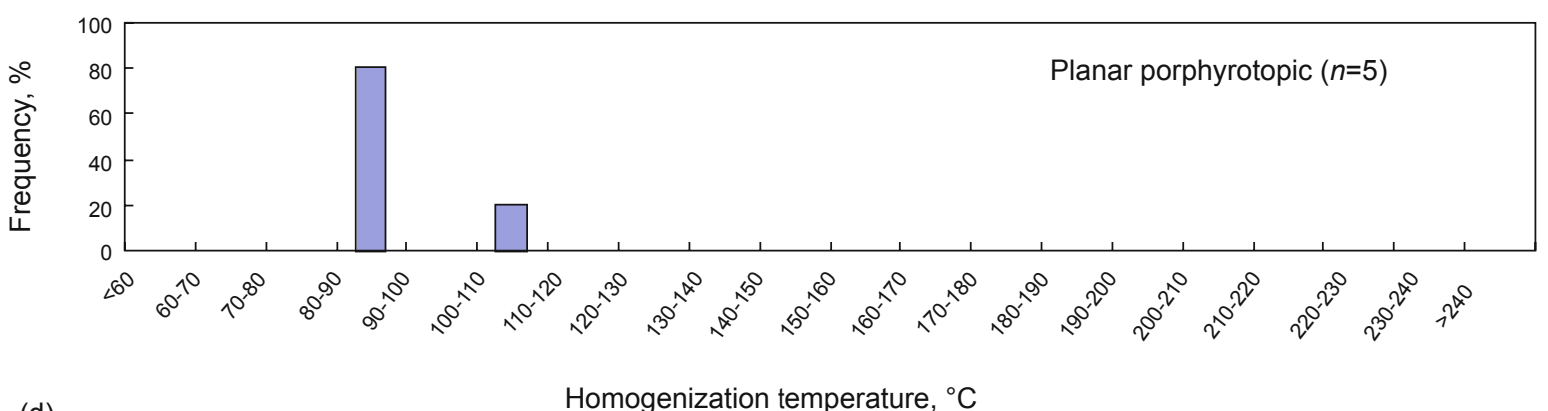

(d)

Homogenization temperature, ${ }^{\circ} \mathrm{C}$

Fig. 8 Histogram of homogenization temperatures of fluid inclusions in different dolomite phases. All samples are taken from the Permian-Triassic successions of the Sichuan Basin and the Lower Paleozoic successions of the Tarim Basin

\section{Discussion}

\subsection{Temperature and fabric-preservation}

The penecontemporaneous dolomite, which formed during early diagenesis, always preserves the fabric of the original limestone, and it has been suggested that dolomitization at low temperatures tends to produce fabric-preserved dolomite. However, there are some exceptions. Davies and Smith (2006) reported that bulbous stromatoporoid 
limestone had undergone hydrothermal dolomitization at over $200{ }^{\circ} \mathrm{C}$ and still preserved the original fabrics. Wei et al (2006) reported that the Neogene dolomite in the Xisha Islands had undergone hydrothermal dolomitization at over $150{ }^{\circ} \mathrm{C}$ and preserved the original fabric of the precursor limestone. As stated above, dolomite with well-preserved fabric (e.g. micritic dolomite, silty dolomite, grain dolomite, and reef dolomite) mainly consists of micritic or silty crystals. The formation temperatures of these dolomites are near atmosphere temperatures (Zhang et al, 2001; Su et al, 2004; Wei et al, 2005; 2006; Huang et al, 2009; Wang et al, 2010; $\mathrm{Li}$ et al, 2011). No measureable gaseous-liquid fluid inclusions were found in the dolomite textures of our samples or in those of previous studies (Drivet and Mountjoy, 1997; Lonnee and Al-Aasm, 2000; Azmy et al, 2009; Azmy and Conliffe, 2010; Lavoie and Chi, 2010; López-Horgue et al, 2010; Ronchi et al, 2012). This may be explained from two perspectives: 1) the sizes of the micritic to fine crystals that formed at atmosphere temperatures were small, leading to correspondingly tiny sizes of fluid inclusions (Liu, 1995). The observation and measurement of these tiny fluid inclusions would be strongly dependent on the resolution of conventional optical microscopy. It was difficult to identify whether the tiny two-phase fluid inclusions were homogenized, or even if the fluid inclusions were twophase or mono-phase. Therefore, microthermometry analysis could not be performed under these circumstances. 2) The abundant mono-phase (i.e. aqueous) fluid inclusions in these dolomite crystals were formed at low temperatures (i.e. room or atmosphere temperatures). Because the temperature is an important factor in the entrapment of fluid inclusions, the higher the temperature of entrapment, the more likely it is that a fluid inclusion will nucleate a bubble (Goldstein, 2001). The contraction coefficient of the solid-phase host mineral (i.e. dolomite) was almost in equilibrium with the contraction coefficient of the liquid-phase fluid at room or atmosphere temperatures (Liu, 1995). Moreover, subsequent diagenesis consisted mainly of heating processes, therefore the equilibrium between the solid and liquid phase had not been changed; consequently, the mono-phase fluid inclusions were maintained. Both cases are related to temperatures; however, there were exceptions in previous research. Davies and Smith (2006) reported that limestone with bulbous stromatoporoid floatstone texture from the Middle Devonian Dunedin Formation of the northeastern British Columbia had been completely dolomitized but preserved the original textures of the host limestone. Biomoldic and vuggy pores developed in the limestone and were lined by saddle dolomite cements. Fluid inclusion analysis of the replacive dolomite yielded a homogenization temperature of $155-188^{\circ} \mathrm{C}$, with a homogenization temperature of $160-235^{\circ} \mathrm{C}$ for porefilling or saddle-lining dolomite cement. Wei et al (2006) reported that the Neogene dolomite in the Xisha Islands had undergone hydrothermal dolomitization at over $150{ }^{\circ} \mathrm{C}$ and still preserved the original fabric of the precursor limestone. Based on the current and previous research (Davies and Smith, 2006; Wei et al, 2006), the temperature and duration of the dolomitization could be considered as factors for evaluating the degree of fabric-preservation. In the absence of hydrothermal events, these two factors would have equal influence on the dolomitization. The dolomitization of penecontemporaneous and earlier burial diagenesis would be associated with low temperatures, and the dolomitization of medium to deep burial diagenesis would be associated with elevated temperatures. Once the hydrothermal events develop at the earlier stage of burial diagenesis, if the neomorphism of the rock had not completely finished or the rock still had abundant porosity (i.e. the rocks still had differences in fabrics and mineralogical stabilities), the fabric-selective dolomitization would also preserve the original fabric of the host rocks. For a progressive burial diagenetic system (without hydrothermal influence), the dolomitization in the subaerial environment at low temperatures during early diagenesis would preserve the original fabrics of the limestone (Figs. 2, 4(c) and 4(d)). Nevertheless, most of these preserved original fabrics would be destroyed by recrystallization during subsequent medium to deep burial diagenesis (Fig. 3). The micritic and silty dolomite, grain dolomite, and reef dolomite with preserved original fabric from the Permian to Triassic successions of the northeastern Sichuan Basin could be seen as an example of dolomitization at low temperatures (Figs. 2, $3,4(\mathrm{c})$, and 4(d)).

\subsection{Temperatures and curved crystal faces}

Sibley and Gregg (1987) suggested that the growing style of a dolomite crystal face has a close relationship with temperature and the degree of fluid supersaturation. The growing style controls whether the crystal faces would be planar or curved. At low supersaturation and/or temperatures, crystal growth occurs by nucleation at active sites and during lateral migration of layers or growth spirals, producing faceted crystals and planar crystal faces. At high supersaturation and/or above certain temperatures (i.e. critical roughening temperature), crystal growth occurs by random addition of atoms to the crystal surface, producing non-planar or curved crystal faces. Gregg and Sibley (1984) and Sibley and Gregg (1987) determined that the temperature range for the boundary between the formation of planar and non-planar dolomites was $50-60{ }^{\circ} \mathrm{C}$ (Fig. 1), which could be seen as the critical temperature (i.e. critical roughening temperature or CRT) at which the dolomite crystal faces begin to become non-planar. However, this temperature range does not indicate that planar dolomite could not develop at temperatures higher than $50-60^{\circ} \mathrm{C}$ (Huang et al, 2009). The $\mathrm{Mg} / \mathrm{Ca}$ ratio could also influence the degree of curvature of the crystalline face and the crystalline morphology. For example, an oversaturated solution with magnesium ions and high $\mathrm{Mg} / \mathrm{Ca}$ ratio also tends to form non-planar crystalline faces, whereas fluids with a low $\mathrm{Mg} / \mathrm{Ca}$ ratio may produce planar dolomites at elevated temperatures (Huang, 2010). All these arguments are still inconclusive and need further investigation.

Whether the crystal faces are curved or not may be influenced by three factors, representing 1) fabric-preserved micritic dolomite sequence, 2 ) replacive crystalline dolomite 
sequence and 3) cement and overgrowth sequence.

\subsubsection{Micritic dolomite sequence with well-preserved fabric}

Most of the micrites in the dolomite with well-preserved fabric do not have an euhedral crystal shape, and could be identified as anhedral crystals with curved crystal faces at high magnification (Fig. 2(a)). These dolomites are associated with evaporites, and develop in the penecontemporaneous or shallow burial environment with hypersaline fluids (e.g. sabkha and some reflux models). No measureable two-phase fluid inclusions were found in these dolomicrites, suggesting a precipitating environment of atmosphere temperatures or very shallow burial temperatures. In addition, formation temperatures estimated by the geologic thermometer using oxygen isotopic data also showed atmosphere temperature or very shallow burial temperatures (Drivet and Mountjoy, 1997; Zhang et al, 2001; Kirmaci and Akdağ, 2005; Wei et al, 2005; Li et al, 2011). Therefore, elevated temperatures may not be the only factor that can curve the dolomite crystal faces. This suggests that the rapid nucleation and crystallization of fluid with high $\mathrm{Mg} / \mathrm{Ca}$ ratio in a hypersaline environment is a major reason for the anhedral shape and curved dolomite crystal faces.

\subsubsection{Replacive sequence of crystalline dolomites}

The two-phase aqueous fluid inclusions in our samples were poorly developed in the planar subhedral to euhedral dolomites. Five gaseous-liquid fluid inclusions were measured in planar dolomite porphyrites, and four of them have a major homogenization temperature range of $80-90{ }^{\circ} \mathrm{C}$ (Fig. 8(d)). The two-phase fluid inclusions of the non-planar anhedral dolomites have a homogenization temperature of 81-203 ${ }^{\circ} \mathrm{C}$, and most of the temperature values lie between $110{ }^{\circ} \mathrm{C}$ and $180{ }^{\circ} \mathrm{C}$ (Table 1; Fig. 8(b)). The replacive nonplanar dolomites have higher formation temperatures than the planar dolomites, indicating that the temperature is also a controlling factor for the curved dolomite crystal faces. The critical temperature for the curved crystal faces is about 80 ${ }^{\circ} \mathrm{C}$ in this study and in previous research (e.g. Zhang, 2000; Zhang et al, 2001; Su et al, 2004; Gasparrini et al, 2003; 2006; Lavoie et al, 2006; Ma et al, 2009; Zhang et al, 2009; Lavoie and Chi, 2010; Shah et al, 2010; Zhang and Luo, 2010; Zhu et al, 2010; Hartig et al, 2011; Jiao et al, 2011), and is higher than $50-60^{\circ} \mathrm{C}$ (Fig. 1; Gregg and Silbey, 1984; Silbey and Gregg, 1987).

\subsubsection{Cements and overgrowth sequence}

The planar subhedral to euhedral dolomite cements and non-planar saddle dolomite cements have well-developed gaseous-liquid fluid inclusions, indicating that directlyprecipitated minerals in fluids at elevated temperatures could easily have formed fluid inclusions and preserved them; moreover, this indicates that the elevated temperatures are significant factors for overcoming the kinetic barrier of dolomite precipitation (Boni et al, 2000; Savard et al, 2000; Yoo et al, 2000; Morrow et al, 2002; Vandeginste et al, 2005; Nader et al, 2007; Huang et al, 2010; Song et al, 2011; Xing et al, 2011a; 2011b). The homogenization temperatures of the fluid inclusions in the planar dolomite cements are lower than those in the non-planar dolomite cements (Table 1); however, the major temperature ranges do not differ significantly (Fig. 8(a) and 8(c)). Therefore, the critical temperature for curved dolomite crystal faces in cement sequences could not be identified clearly. In the overgrowth sequence, the overgrowth parts have higher homogenization temperatures than the host dolomite crystals, suggesting that the dolomite cements have higher formation temperatures than the replacive dolomites (Gasparrini et al, 2003; Ronchi et al, 2012), and that the temperature is also a controlling factor for curved crystal faces.

\section{Conclusions}

1) Dolomite texture is closely related to its formation temperature. (i) In dolomites of replacive or cement genesis, the non-planar dolomites have higher formation temperatures than the planar dolomites. In dolomite cements, the nonplanar saddle dolomite cements have higher formation temperatures than the planar subhedral to euhedral dolomite cements. Our data suggest that for replacive dolomites, the critical temperature of the curved crystal faces is around $80{ }^{\circ} \mathrm{C}$. (ii) Dolomite micrites in most fabric-preserving dolomites were formed in the earlier diagenetic and subaerial environment. The preserved original fabrics are associated with low environmental temperatures and dolomitization during early diagenesis. The earlier-developed hydrothermal dolomitization may preserve the original fabrics of the host rocks. (iii) For both planar and non-planar dolomites, the dolomite cements have higher formation temperatures than the replacive dolomites. The planar dolomite cements have higher formation temperatures than the replacive planar dolomites. The non-planar saddle dolomite cements have higher formation temperatures than replacive non-planar anhedral dolomites.

2) In dolomite micrites and silts that formed in penecontemporaneous and shallow burial environment and in planar subhedral to euhedral replacive dolomite crystals that formed in the early diagenesis stage, the formed fluid inclusions are rarely preserved in subsequent burial diagenesis at elevated geothermal temperatures. However, dolomites that were formed by shallow burial hydrothermal dolomitization (e.g. saddle dolomite cements) have well-developed fluid inclusions, possibly because the subsequent burial diagenesis did not provide temperatures higher than the formation temperatures of these dolomites.

3) Dolomite textures are not only controlled by temperature. Our research indicates that non-planar dolomite can form at low temperatures under conditions of high supersaturation although such occurrences are probably rare. Therefore, in certain cases, petrographic recognition of dolomite texture provides a quick and easy way to determine if dolomite formed at relatively high temperatures, above CRT, either by neomorphism of an earlier dolomite or by replacement of limestone at relatively low temperatures. This may be helpful to constrain conditions when studying dolomite formation mechanism and environment.

\section{Acknowledgements}

This study was supported by the National Natural 
Science Foundation (Nos. 41172099, 41272130). We'd like to express our thanks to all the members who participated in the fieldwork: Chi Yingliu, Bao Dongmei and Jiang Qinchun from Research Institute of Petroleum Exploration and Development, PetroChina; Li Zhiming, Fan Ming, Xu Ershe and Zhang Wentao from Wuxi Research Institute of Petroleum Geology, SINOPEC. We also sincerely thank the editor and anonymous reviewers for their constructive comments.

\section{References}

Azmy K and Conliffe J. Dolomitization of the lower St. George Group on the Northern Peninsula in western Newfoundland: Implications for lateral distribution of porosity. Bulletin of Canadian Petroleum Geology. 2010. 58(4): 361-374

Azmy K, Knight I, Lavoie D, et al. Origin of dolomites in the Boat Harbour Formation, St. George Group, in western Newfoundland, Canada: Implications for porosity development. Bulletin of Canadian Petroleum Geology. 2009. 57(1): 81-104

Boni M, Parente G, Bechstädt T, et al. Hydrothermal dolomites in SW Sardinia (Italy): evidence for a widespread late-Variscan fluid flow event. Sedimentary Geology. 2000. 131(3-4): 181-200

Braithwaite C J R and Rizzi G. The geometry and petrogenesis of hydrothermal dolomites at Navan, Ireland. Sedimentology. 1997. 44(3): 421-440

Brice J C. The Growth of Crystals from Liquids. New York: NorthHolland Pub. Co.. 1973

Chen Y and Ge Y J. Experimental study on the modes of hydrocarbonbearing inclusion trapped in carbonate rock reservoirs. Rock and Mineral Analysis. 2010. 29(3): 217-220 (in Chinese)

Davies G R and Smith Jr L B. Structurally controlled hydrothermal dolomite reservoir facies: An overview. AAPG Bulletin. 2006. 90(11): 1641-1690

Drivet E and Mountjoy E W. Dolomitization of the Leduc Formation (Upper Devonian), southern Rimbey-Meadowbrook reef trend, Alberta. Journal of Sedimentary Research. 1997. 67(3): 411-423

Gasparrini M, Bakker R J, Bechstadt T, et al. Hot dolomites in a Variscan foreland belt: hydrothermal flow in the Cantabrian Zone (NW Spain). Journal of Geochemical Exploration. 2003. 78-79: 501-507

Gasparrini M, Bakker R J and Bechstadt T. Characterization of dolomitizing fluids in the Carboniferous of the Cantabrian zone (NW Spain): a fluid-inclusions study with Cryo-Raman spectroscopy. Journal of Sedimentary Research. 2006. 76(12): 1304-1322

Goldstein R H. Fluid inclusions in sedimentary and diagenetic systems. Lithos. 2001. 55(1-4): 159-193

Gregg J M and Sibley D F. Epigenetic dolomitization and the origin of xenotopic dolomite texture. Journal of Sedimentary Research. 1984. 54(3): 908-931

Hao F, Zou H Y and Gong Z S. Preferential petroleum migration pathways and prediction of petroleum occurrence in sedimentary basins: A review. Petroleum Science. 2010. 7(1): 2-9

Hartig K A, Soreghan G S, Goldstein R H, et al. Dolomite in Permian paleosols of the Bravo Dome $\mathrm{CO}_{2}$ Field, U.S.A.: Permian reflux followed by late recrystallization at elevated temperature. Journal of Sedimentary Research. 2011. 81(4): 248-265

Huang Q Y, Zhang S N, Ding X Q, et al. Origin of dolomite of Ordovician Majiagou Formation, western and southern margin of the Ordos Basin. Petroleum Geology \& Experiment. 2010. 32(2): 147-158 (in Chinese)

Huang S J. Carbonate Diagenesis. Beijing: Geological Publishing House. 2010 (in Chinese)

Huang S J, Huang K K, Li Z M, et al. TSR-derived authigenic calcites in Triassic dolomite, NE Sichuan Basin, China - a case study of well
HB-1 and well L-2. Journal of Earth Science. 2012. 23(1): 88-96

Huang S J, Lü J, Lan Y F, et al. The main texture of dolomite of Middle Permian, western Sichuan Basin: Concurrently on the differences with Upper Permian-Triassic, Northeast Sichuan Basin. Acta Petrologica Sinica. 2011. 27(8): 2253-2262 (in Chinese)

Huang S J, Tong H P, Liu L H, et al. Petrography, geochemistry and dolomitization mechanisms of Feixianguan dolomites in Triassic, NE Sichuan, China. Acta Petrologica Sinica. 2009. 25(10): 23632372 (in Chinese)

Human H J, Van Der Eerden J P, Jetten L A M J, et al. On the roughening transition of biphenyl: Transition of faceted to nonfaceted growth of biphenyl for growth from different organic solvents and the melt. Journal of Crystal Growth. 1981. 51(3): 589-600

Jiao C L, He Z L, Xing X J, et al. Tectonic hydrothermal dolomite and its significance of reservoirs in Tarim Basin. Acta Petrologica Sinica. 2011. 27(1): 277-284 (in Chinese)

Kirkpatrick R J. Kinetics of crystallization of igneous rocks. In: Lasage A C and Kirkpatrick R J, eds., Kinetics of Geochemical Processes: Reviews in Mineralogy. Mineralogical Society of America. 1981. 8: 321-397

Kirmaci M Z and Akdağ K. Origin of dolomite in the Late CretaceousPaleocene limestone turbidites, Eastern Pontides, Turkey. Sedimentary Geology. 2005. 181(1-2): 39-57

Lavoie D and Chi G X. Lower Paleozoic foreland basins in eastern Canada: tectono-thermal events recorded by faults, fluids and hydrothermal dolomites. Bulletin of Canadian Petroleum Geology. 2010. 58(1): 17-35

Lavoie D, Chi G, Brennan-Alpert P, et al. Hydrothermal dolomitization in the Lower Ordovician Romaine Formation of the Anticosti Basin: significance for hydrocarbon exploration. Bulletin of Canadian Petroleum Geology. 2006. 53(4): 454-471

Lewis B. Nucleation and growth theory. Crystal Growth. 1980. 23-63

Li P C, Chen G H, Zeng Q S, et al. Genesis of Lower Ordovician dolomite in central Tarim Basin. Acta Sedimentologica Sinica. 2011. 29(5): 842-856 (in Chinese)

Liu C Y, Zhou Y Q, Chen Y, et al. Experimental techniques and quantitative analysis of synthetic carbonate fluid inclusions. Rock and Mineral Analysis. 2004. 23(3): 161-167 (in Chinese)

Liu C Y, Zhou Y Q, Chen Y, et al. Using high-pressure vessel to synthesize the carbonate fluid inclusions. Bulletin of the Chinese Ceramic Society. 2007. 26(1): 168-172 (in Chinese)

Liu D H. Fluid inclusion studies: an effective means for basin fluid investigation. Earth Science Frontiers. 1995. 2(3-4): 149-154 (in Chinese)

Liu D H, Xiao X M, Tian H, et al. Fluid inclusion types and their geological significance in petroliferous basins. Oil \& Gas Geology. 2008. 29(4): 491-501 (in Chinese)

Lonnee $\mathrm{J}$ and Al-Aasm I S. Dolomitization and fluid evolution in the Middle Devonian Sulphur Point Formation, Rainbow South Field, Alberta: petrographic and geochemical evidence. Bulletin of Canadian Petroleum Geology. 2000. 48(3): 262-283

López-Horgue M A, Iriarte E, Schröder S, et al. Structurally controlled hydrothermal dolomites in Albian carbonates of the Asón valley, Basque Cantabrian Basin, Northern Spain. Marine and Petroleum Geology. 2010. 27(5): 1069-1092

Ma F, Xu H X, Gu J Y, et al. Cambrian dolomite origin and reservoir evolution in east Tarim Basin. Petroleum Exploration and Development. 2009. 36(2): 144-155 (in Chinese)

Machel H G. Concepts and models of dolomitization: A critical reappraisal. In: Braithwaite C J R, Rizzi G and Darke G, eds. The Geometry and Petrogenesis of Dolomite Hydrocarbon Reservoirs. London: Geological Society of London Special Publications. 2004. 7-63

Morrow D W, Zhao M W and Stasiuk L D. The gas-bearing Devonian 
Presqu'ile Dolomite of the Cordova embayment region of British Columbia, Canada: dolomitization and the stratigraphic template. AAPG Bulletin. 2002. 86(9): 1609-1638

Nader F H, Swennen R and Ellam R M. Field geometry, petrography and geochemistry of a dolomitization front (Late Jurassic, central Lebanon). Sedimentology. 2007. 54(5): 1093-1120

Ronchi P, Masetti D, Tassan S, et al. Hydrothermal dolomitization in platform and basin carbonate successions during thrusting: a hydrocarbon reservoir analogue (Mesozoic of Venetian Southern Alps, Italy). Marine and Petroleum Geology. 2012. 29(1): 68-89

Savard M M, Chi G, Sami T, et al. Fluid inclusion and carbon, oxygen, and strontium isotope study of the Polaris Mississippi Valley-type $\mathrm{Zn}-\mathrm{Pb}$ deposit, Canadian Arctic Archipelago: implications for ore genesis. Mineralium Deposita. 2000. 35(6): 495-510

Shah M M, Nader F H, Dewit J, et al. Fault-related hydrothermal dolomites in Cretaceous carbonates (Cantabria, northern Spain): Results of petrographic, geochemical and petrophysical studies. Bulletin de la Société Géologique de France. 2010. 181(4): 391-407

Sibley D F and Gregg J M. Classification of dolomite rock textures. Journal of Sedimentary Research. 1987. 57(6): 967-975

Song G Y, Liu S G, Li S M, et al. Origin of Dengying saddle dolomite in well Lin-1 in southeastern part of Sichuan Basin. Marine Origin Petroleum Geology. 2011. 16(2): 53-60 (in Chinese)

Su L P, Luo P, Hu S R, et al. Diagenesis of oolitic bank of the Feixianguan Formation of Lower Triassic in Luojiazhai Gas Field, northeastern Sichuan Province. Journal of Palaeogeography. 2004. 6(2): 182-190 (in Chinese)

Tao S Z. Premise conditions and key problems of applied study of inclusion in oil-gas geology. Chinese Journal of Geology. 2004. 39(1): 77-91 (in Chinese)

Vandeginste V, Swennen R, Gleeson S A, et al. Zebra dolomitization as a result of focused fluid flow in the Rocky Mountains Fold and Thrust Belt, Canada. Sedimentology. 2005. 52(5): 1067-1095

Wang D, Chen D Z, Yang C C, et al. Classification of texture in burial dolomite. Acta Sedimentologica Sinica. 2010. 28(1): 17-25 (in Chinese)

Wang S Y, Jiang X Q, Guan H L, et al. Diagenesis effects of Lower Triassic Feixianguan Formation reservoir in Puguang Gas Field, northeast Sichuan. Petroleum Geology \& Experiment. 2010. 32(4): 366-372 (in Chinese)

Warren J. Dolomite: occurrence, evolution and economically important associations. Earth-Science Reviews. 2000. 52(1-3): 1-81

Weeks J D and Gilmer G H. Dynamics of crystal growth. Advances in Chemical Physics. 1979. 40. 157-228

Wei G Q, Yang W, Zhang L, et al. Dolomitization genetic model of Feixianguan Group oolitic beach reservoir in northeast Sichuan Basin. Natural Gas Geoscience. 2005. 16(2): 162-166 (in Chinese)

Wei X, Zhu Y J, Xu H, et al. Discussion on Neogene dolostone forming condition in Xisha Islands: Evidences from isotope $\mathrm{C}$ and $\mathrm{O}$ and fluid inclusions. Acta Petrologica Sinica. 2006. 22(9): 2394-2404 (in Chinese)

Xing F C, Zhang W H and Li S T. Influence of hot fluids on reservoir property of deep burial dolomite strata and its significance for petroleum exploration: A case study of Keping outcrop in Tarim Basin. Acta Petrologica Sinica. 2011a. 27(1): 266-276 (in Chinese)

Xing X J, Jiao C L, Wang Y, et al. Characteristics and origin of Cambrian dolomite, northern Tarim Basin. Petroleum Geology \& Experiment. 2011b. 33(2): 130-136 (in Chinese)

Yoo C M, Gregg J M and Shelton K L. Dolomitization and dolomite neomorphism: Trenton and Black River limestones (Middle Ordovician) northern Indiana, U.S.A. Journal of Sedimentary Research. 2000. 70(1): 265-274

Zhang C L, Zhang Y S, Kang Q F, et al. Dolomite genesis of Ordovician system in Maliu formation, southern Ordos Basin. Acta Petrolei Sinica. 2001. 22(3): 22-26 (in Chinese)

Zhang $\mathrm{J}$ and Luo P. Genesis of Ordovician matrix-porosity dolomite reservoir in the Tarim Basin. Petroleum Geology \& Experiment. 2010. 32(5): 470-474 (in Chinese)

Zhang N, Xing Y L, Zeng Y, et al. Characteristics of fluid inclusions of Cambrian dolomite and hydrocarbon-generation history in the Eastern Tarim Basin. Acta Petrolei Sinica. 2009. 30(5): 692-697 (in Chinese)

Zhang Y S. Mechanism of deep burial dolomitization of massive dolostones in the Middle Majiagou Group of the Ordovician, Ordos Basin. Acta Sedimentologica Sinica. 2000. 18(3): 424-430 (in Chinese)

Zhu D Y, Jin Z J and Hu W X. Hydrothermal recrystallization of the Lower Ordovician dolomite and its significance to reservoir in northern Tarim Basin. Science in China Earth Sciences. 2010. 53(3): 368-381

(Edited by Hao Jie) 